\title{
NEW FAUNISTIC AND TAXONOMIC NOTES \\ ON THE HAPLOGYNE AND CRIBELLATE SPIDERS \\ (ARANEAE: DICTYNIDAE, DYSDERIDAE, ERESIDAE, FILISTATIDAE, SICARIIDAE) FROM THREE BALKAN COUNTRIES
}

\author{
Maria Naumova ${ }^{1}$ and Christo Deltshev ${ }^{1,2}$ \\ ${ }^{1}$ Institute of Biodiversity and Ecosystem Research, Bulgarian Academy of Sciences \\ 1 Tzar Osvoboditel Blvd., 1000 Sofia, Bulgaria \\ E-mail:munny@abv.bg, https://orcid.org/0000-0003-0060-048X \\ ${ }^{2}$ National Museum of Natural History, Bulgarian Academy of Sciences, 1000 Sofia, Bulgaria \\ E-mail: deltshev@gmail.com,https://orcid.org/0000-0003-0539-5673
}

In this paper, we report for the first time two spider species for Albania, four for Bulgaria and two for Greece: Altella lucida (Simon, 1874) (Bulgaria), Eresus moravicus Rezác, 2008 (Bulgaria and Greece), Filistata insidiatrix (Forsskål, 1775) (Albania), Harpactea samuili Lazarov, 2006 (Greece), Loxosceles rufescens (Dufour, 1820) (Albania), Pritha parva Legittimo, Simeon, Di Pompeo et Kulczycki, 2017 (Bulgaria) and Pritha vestita (Simon, 1873) (Bulgaria). The recently described species $P$. parva is the first report for the Balkan Peninsula, while $P$. vestita is the first record for mainland Europe. Their congener Pritha nana (Simon, 1868) is removed from the Bulgarian checklist of spiders (misidentification). As a result of our report, the number of spider species increases to 571, 1049 and 1183 in Albania, Bulgaria and Greece, respectively.

Keywords: Araneae, Albania, Arachnida, Bulgaria, Greece, checklist update.

\section{INTRODUCTION}

Although the Balkan Peninsula is well known as a biodiversity hotspot, especially from arachnological perspective, it is still unequally explored (GRIFFiths et al. 2004, CutTelod et al. 2008). While the number of spider species is relatively high in Bulgaria - 1044 species (Blagoev et al. 2018, Dimitrov et al. 2019, Naumova 2019, Naumova et al. 2019) and in Greece - 1181 species (Bosmans \& Chatzaki 2005, Nentwig et al. 2020), in Albania it is much lower - 569 species (Blick 2018, KŮrka et al. 2020, Naumova 2020).

The families Dictynidae, Dysderidae, Eresidae, Filistatidae and Sicariidae are objects of active research in both taxonomic and faunistic aspects within Europe and in general. Intensive studies in the last decade have led to several revisions and descriptions of new species of the European Filistatidae (Legitтimo et al. 2017, Zonstein \& Marusik 2019) and Eresidae (Rezác et al. 2008, Kovács et al. 2010, 2015). As a result, the taxonomic status of many species was clarified, and their correct identification facilitated. This study aims to contribute to the knowl- 
edge of both the less studied spider fauna of Albania and the relatively wellstudied faunas of Bulgaria and Greece, as well as to add original photographs of some essential taxonomic features of all seven rare or poorly illustrated species.

\section{MATERIAL AND METHODS}

The material is housed in the collections of the Institute of Biodiversity and Ecosystem Research (IBER) and National Museum of Natural History (NMNHS) at the Bulgarian Academy of Sciences, Sofia and the Centre for Biodiversity Genomics (CBG) in Canada, Guelph. The specimens were collected by hand picking, sieving leaf litter or by pitfall traps and then preserved in 70-80\% ethanol. The digital images were taken with a Canon EOS 1100D digital camera attached to an Amplival microscope and processed using Photoshop CS6 software. Nomenclature follows the WSC (2020), families and species are listed alphabetically. Geographical coordinates are given in decimal degrees and the localities are visu-

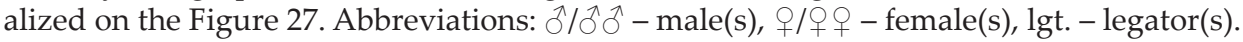

\section{RESULTS}

As a result of our investigation, new faunistic data about seven spider species from five families are presented below. We report two spiders as new for Albania, four as new for Bulgaria and two as new for Greece. The species Pritha vestita (Simon, 1873) is the first record for Europe mainland (after Corsica Island) and P. parva Legittimo, Simeon, Di Pompeo et Kulczycki, 2017 is new for the Balkan Peninsula. Digital images of the essential taxonomic features were added for: Altella lucida (Simon, 1874) (Figs 1-2), Eresus moravicus Rezác, 2008 (Figs 3-7), Filistata insidiatrix (Forsskål, 1775) (Figs 8-11), Harpactea samuili Lazarov, 2006 (Figs 12-14), Loxosceles rufescens (Dufour, 1820) (Figs 15-18), Pritha parva Legittimo, Simeon, Di Pompeo et Kulczycki, 2017 (Figs 19-22) and P. vestita (Simon, 1873) (Figs 23-26).

\section{Family: Dictynidae Altella lucida (Simon, 1874)}

Material (deposited in CBG): BULGARIA: 1 , Western Stara Planina Mts, Sofia (Kremikovtsi ward), N 42.7882 ${ }^{\circ}$, E 23.4812 ${ }^{\circ}, 645 \mathrm{~m}$ a.s.1., 27.03.2017, lgt. M. Naumova. In open dry sunny habitat, with scarce vegetation, under stone.

The species is described from France by Simon (1874) and is distributed from the Azores to the west to eastern Turkey, and from Great Britain to Crimean Peninsula (Roberts 1985, Borges \& Wunderlich 2008, Danişman et al. 2014, KovBLyUK et al. 2016, WSC 2020). The closest reported localities to Bulgaria are from North Macedonia and three Greek islands (Chios, Lesvos and Naxos) (PARAschI 1988, Bosmans et al. 2009, Russell-Smith et al. 2011, Nentwig et al. 2020). 


\section{Family: Dysderidae \\ Harpactea samuili Lazarov, 2006}

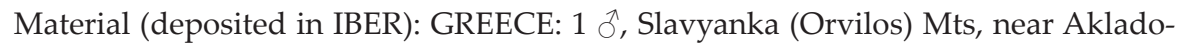
hori village, $\mathrm{N} 41.3200^{\circ}$, E 23.5658 ${ }^{\circ}, 591 \mathrm{~m}$ a.s.1., 05.09-15.10.2019, pitfall traps, lgt. M. Naumova; habitat: grassland, with bushes (Prunus spinosa L. and Rosa sp.) and single oak trees (Quercus cerris L.) between cultivated fields and vineyards; $1 \AA$, Sharlia Mts, near Sidirokastro, $\mathrm{N} 41.2581^{\circ}$, E 23.4137 219 m a.s.1., 06.06-07.08.2019, pitfall traps, lgt. M. Naumova, habitat: stone pit with scarce vegetation.

This species is known only from Bulgaria and North Macedonia (LAzarov 2006, Stefanovska et al. 2008, Blagoev et al. 2018). The new records in Greece are expected since the respective sites are located very close to the borders of both countries (Fig. 27).

\section{Family: Eresidae \\ Eresus moravicus Rezác, 2008}

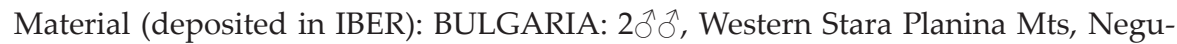
shevo village, pasture, N $42.7286^{\circ}$, E 23.7026 ${ }^{\circ}, 695 \mathrm{~m}$ a.s.1., 10.05.1968; $10^{\lambda}$, South Black Sea

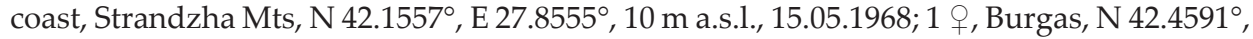
E 27.4394 ${ }^{\circ}, 3$ m a.s.l., 02.06.2009, lgt. M. Naumova; 1 ㅇ, Sliven, N 42.6571 ${ }^{\circ}$, E 26.2849 ${ }^{\circ}, 191$

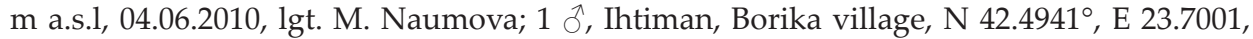
$780 \mathrm{~m}$ a.s.l., 25.05.2013, lgt. T. Trifonov; 1 ㅇ, Plovdiv, Zelenikovo village, N $42.4069^{\circ}$, E $25.0839^{\circ}, 315 \mathrm{~m}$ a.s.1., 03.06.2014, lgt. G. Glushkov; 1 ठ̊, Plovdiv, Grebnata baza place, N

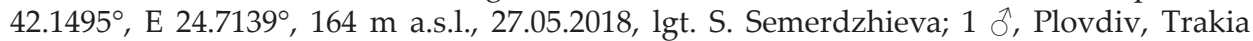
ward, $\mathrm{N} 42.1341^{\circ}$, E 24.7849 ${ }^{\circ}, 165 \mathrm{~m}$ a.s.l., 21.05.2018, lgt. R. Bor; 1 , Plovdiv, Kyuchuka

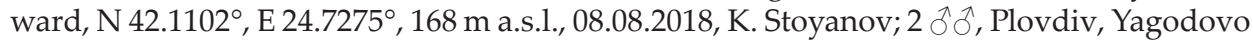
village, $\mathrm{N} 42.1160^{\circ}$, E $24.8520^{\circ}$, $158 \mathrm{~m}$ a.s.l., 05-10.06.2018, lgt. V. Genchev; 3 ふै ồ, Plovdiv,

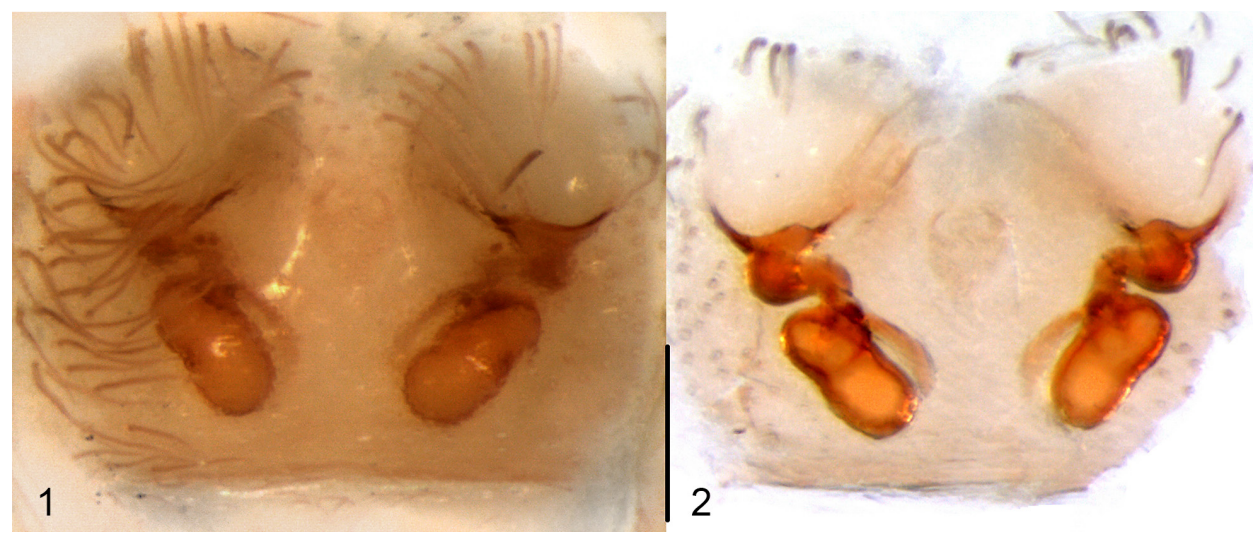

Figs 1-2. Altella lucida, female genitalia: 1 = epigyne, ventral view, 2 = vulva, dorsal view. Scale line: $0.1 \mathrm{~mm}$ 


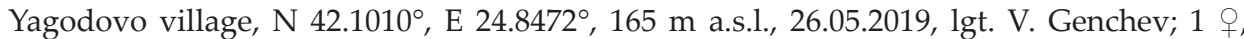
Eastern Rhodopes Mts, Kardzhali, N 41.6325, E 25.3933, 250 m a.s.1., 07.2014; 1 ô, Central Predbalkan, Byala Reka village, N 43.1330', E 25.2178 ${ }^{\circ}, 224$ m a.s.l., 20.05.2016, lgt. M.

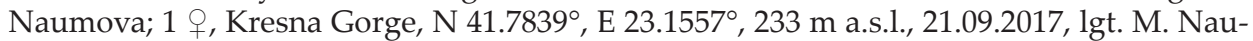

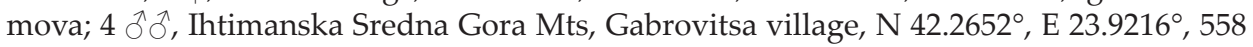
$\mathrm{m}$ a.s.1., 21.04-08.05.2018, lgt. E. Vacheva, habitat: a glade between oak trees; GREECE: 1 , , Sengelska Mts, Krushevska river near Fea Petra village, N 41.2742 ${ }^{\circ}$, E 23.4365 ${ }^{\circ}, 200 \mathrm{~m}$ a.s.l., 08.05.2017, lgt. M. Naumova; 1 ô, near Solun (Tessaloniki), 2 km NW of Kolhiko village, N $40.7045^{\circ}$, E $23.2608^{\circ}, 140 \mathrm{~m}$ a.s.l., 20.05.2017, lgt. M. Naumova.
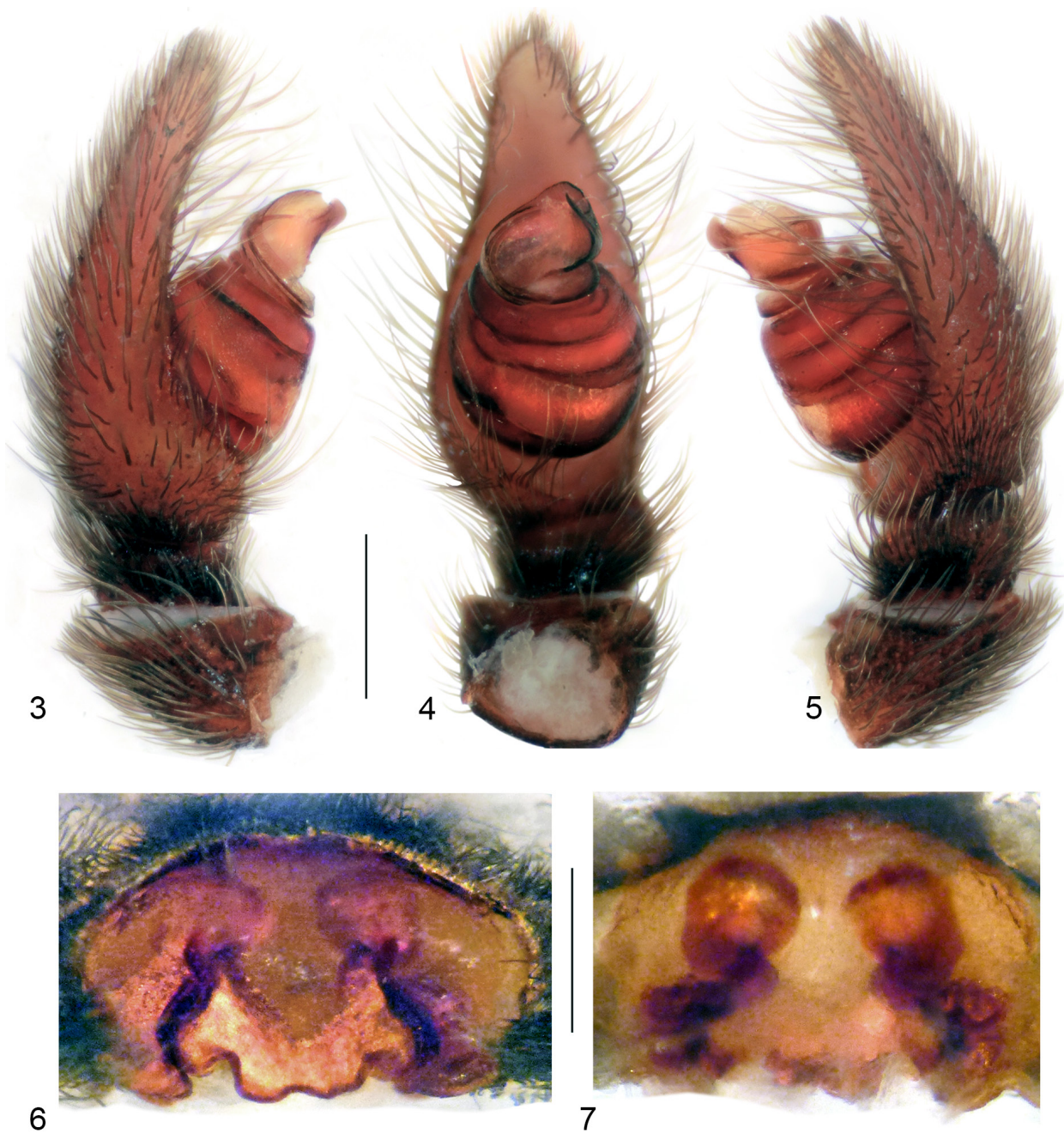

Figs 3-7. Eresus moravicus left male palp (3-5) and female genitalia $(6,7): 3=$ prolateral, $4=$ ventral and $5=$ retrolateral views, $6=$ epigyne, ventral view, $7=$ vulva, dorsal view. Scale line: $0.5 \mathrm{~mm}$ 
Recently described species is reported from Austria, Czech Republic, Hungary, Slovakia, Serbia and Albania (Rezíc et al. 2008, Grbic \& SAvic 2010, Naumova et al. 2016).

Our specimens correspond well to the original description, both in genital and somatic features. The females were black with yellow-orange front of the prosoma. The males had red hairs covering the posterior part of the carapace, femora of the legs II, and all segments of III and IV pairs of legs, except the tarsi, which were brownish. All males were found in spring (April-June).

\author{
FAMILY: Filistatidae \\ Filistata insidiatrix (Forsskål, 1775)
}

Material (deposited in IBER): ALBANIA: $1 \hat{0}, 3$ 우, Saranda district, Mesopotam

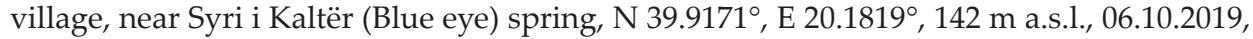
lgt. M. Naumova. Inside dead parts of Oriental plane trees (Platanus orientalis L.). Identified according to ZoNSTEIN \& MARUSIK (2019).

Filistata insidiatrix is known from Cabo Verde and the Iberian Peninsula, through the northern Mediterranean countries and Hungary to Turkmenistan and the southern Mediterranean, Turkey and the Middle East (Zonstein \& MARUsik 2019). The family Filistatidae has been recently reported from Albania on the base of a single specimen of Filistata Latreille, 1810 with the assumption of F. insidiatrix (undetermined to species level as the specimen was immature) (Naumova 2020).

\title{
Pritha parva Legittimo, Simeon, Di Pompeo et Kulczycki, 2017
}

Material (deposited in IBER): BULGARIA: $3 \hat{\jmath}$, Tracian lowland near Plovdiv, Yagodovo village, $\mathrm{N} 42.1107^{\circ}$, E $24.8510^{\circ}, 159 \mathrm{~m}$ a.s.l., 26-30.04.2018, lgt. V. Genchev. On the house wall and under stones in the yard. Identified according to Legittimo et al. (2017).

The species is recently described and with known distribution only in France, Italy and Switzerland (LegitTimo et al. 2017). The records from Bulgaria greatly extended the known range to the east and suggest a much wider distribution within Europe.

\section{Pritha vestita (Simon, 1873)}

Lazarov 2005: $5 \hat{\jmath} \hat{\jmath}$, sub P. nana (Simon, 1868), misidentified.

Material (deposited in NMNHS): BULGARIA: $3 \hat{\jmath} \widehat{\partial}, 2 \mathrm{~km}$ Maleshevska Mts, South from Kamenitsa village, N 41.6444 ${ }^{\circ}$, E 23.1703 ${ }^{\circ}$, 170-240 $\mathrm{m}$ a.s.l., 31.05-23.06.2002, pitfall

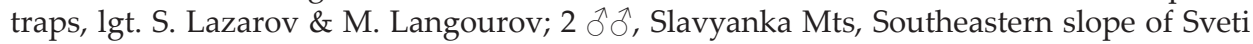




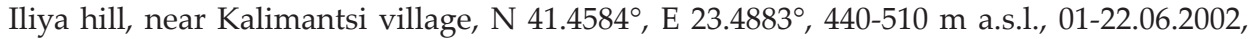
pitfall traps, lgt. S. Lazarov \& M. Langourov. In kermes oak (Quercus coccifera L.) association (pseudomaquis). Identified according to Simon $(1873,1914)$ and LegitTimo et al. (2017).

The species was described from Corsica Island and probably was found in Algeria and Libya (Bosmans unpubl.).

\section{Family: Sicariidae}

Loxosceles rufescens (Dufour, 1820)

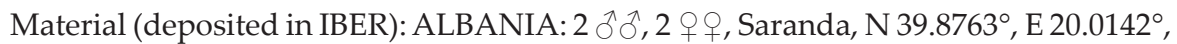
118 m a.s.l., 06.10.2019, lgt. M. Naumova \& T. Trifonov. In open, dry and sunny habitat without vegetation, between newly built houses, under stones.

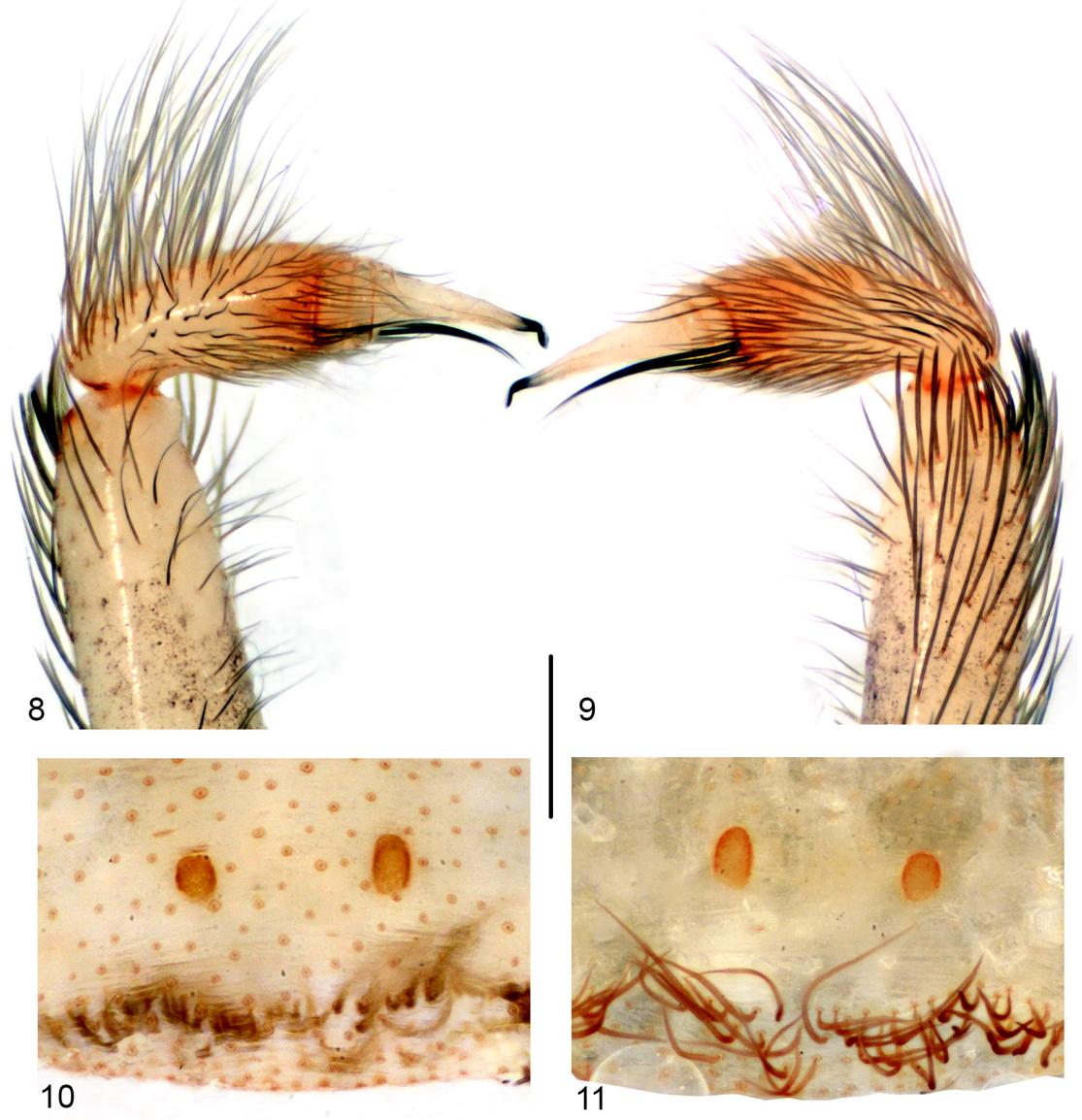

Figs 8-11. Filistata insidiatrix left male palp $(8,9)$ and female vulva $(10,11)$ different views: $8=$ prolateral, $9=$ retrolateral, $10=$ ventral, $11=$ dorsal. Scale bar: $0.3 \mathrm{~mm}$ 

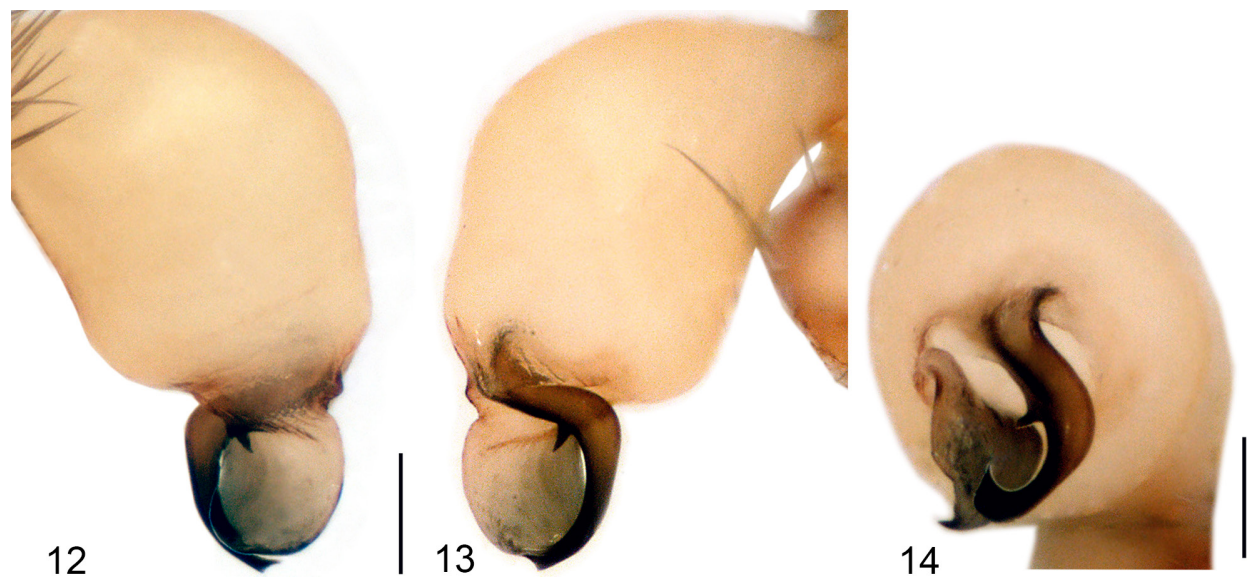

Figs 12-14. Harpactea samuili, left male palp, different views: 12 = prolateral, 13 = retrolateral, 14 = apical view. Scale bar: $0.2 \mathrm{~mm}$ (Figs 12, 13), $0.1 \mathrm{~mm}$ (Fig. 14)
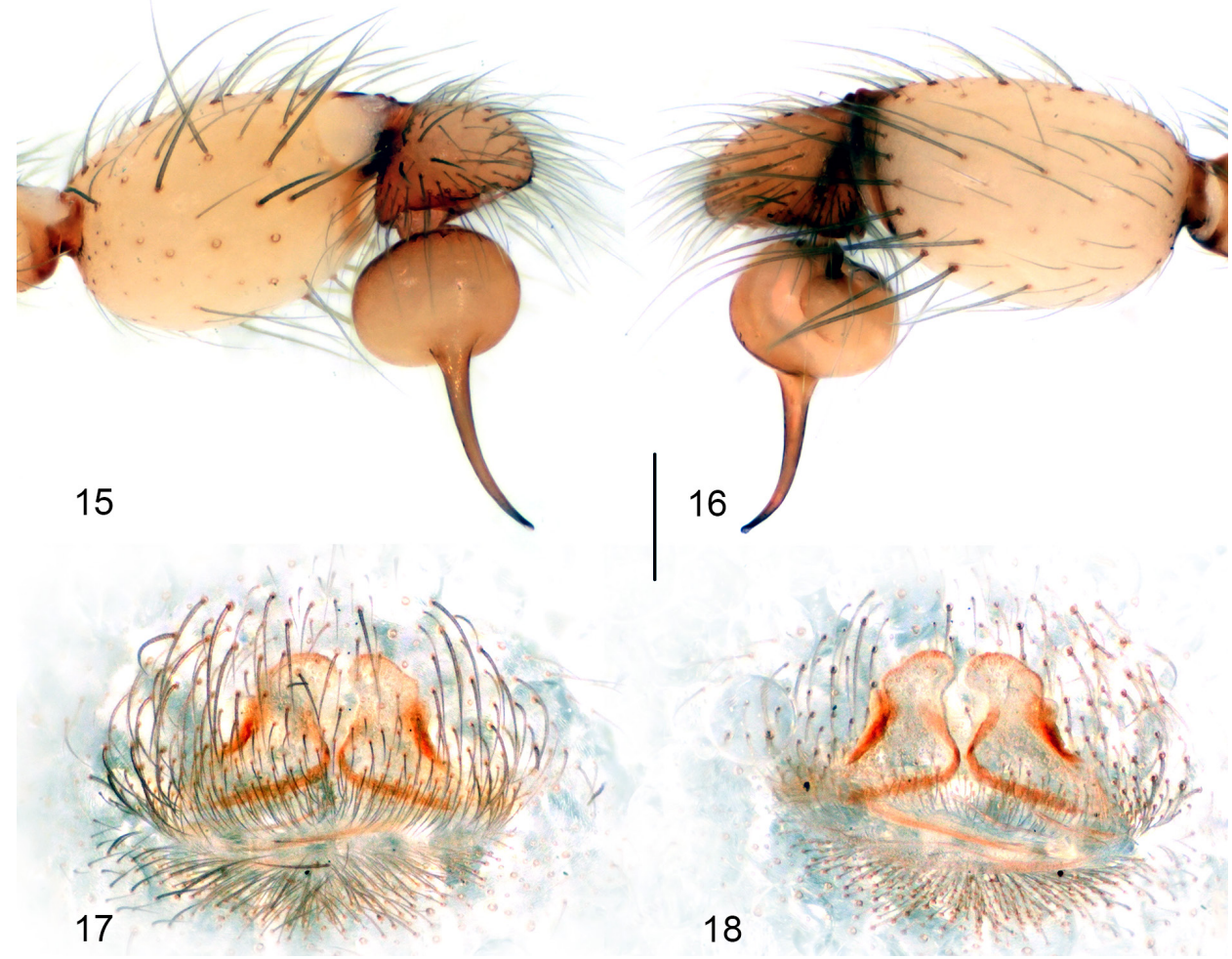

Figs 15-18. Loxosceles rufescens, left male palp $(15,16)$ and female vulva $(17,18)$, different views: 15 = prolateral, 16 = retrolateral, $17=$ ventral, $18=$ dorsal. Scale bar: $0.3 \mathrm{~mm}$ 
The original range of L. rufescens is in the circum-Mediterranean region. However, due to human activity, it is now distributed in Southern Europe and Northern Africa to Iran and introduced in USA, Mexico, Macaronesia,

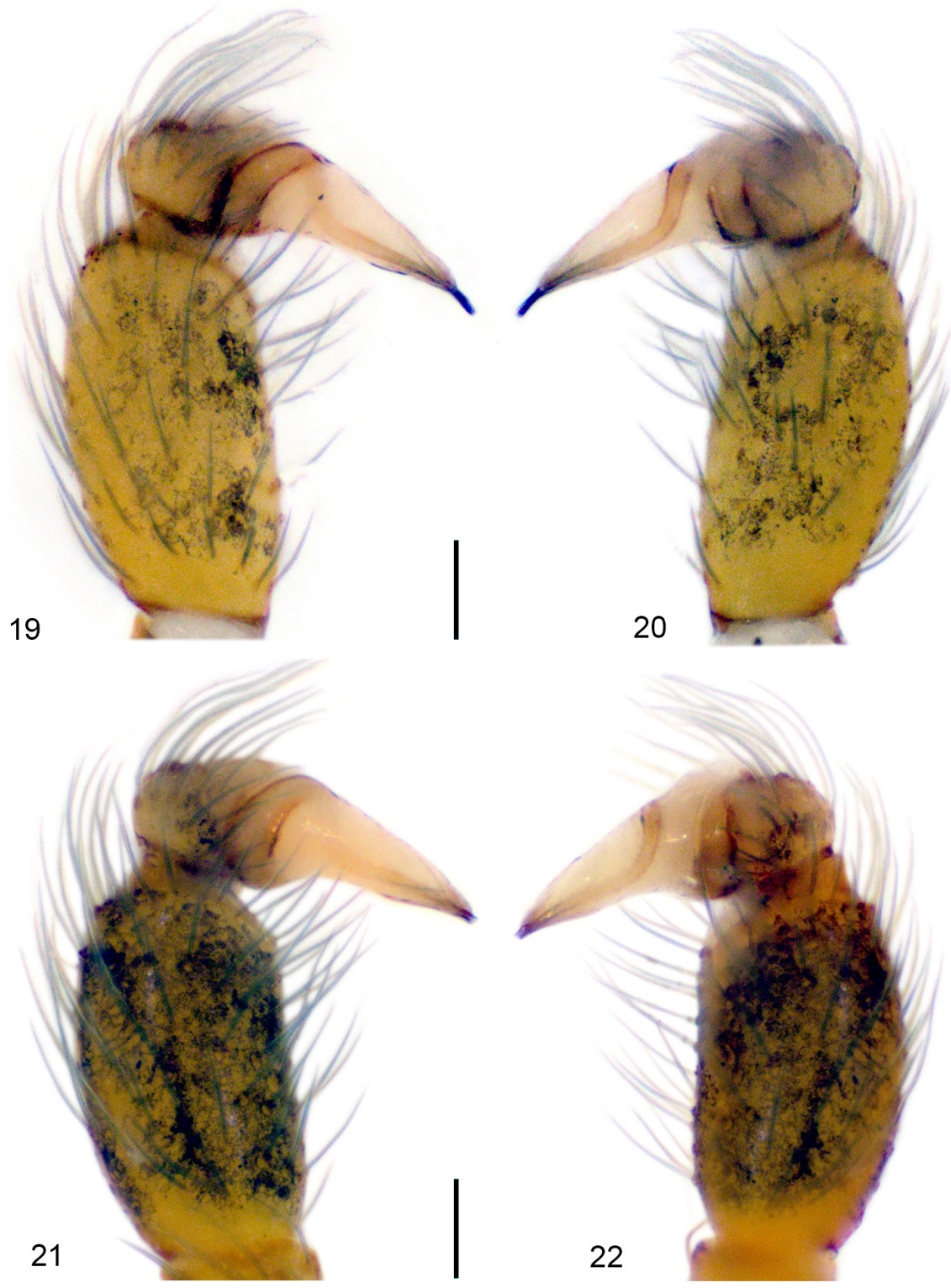

Figs 19-22. Pritha parva (two specimens with slight variations in the shape of the tibia and the bulbus), left male palp with normal $(19,20)$ and with broken tip of embolous $(21,22)$ : 19,21 = prolateral view, 20, 22 = retrolateral view. Scale bar: $0.1 \mathrm{~mm}$ 
South Africa, India, China, Japan, Korea, Laos, Thailand, Australia, Hawaii (Gertsch \& Ennik 1983, Harvey 1996, Mirshamsi et al. 2013, С homphuphuang et al. 2016, Trivedi \& DAL 2019, WSC 2020). For the Balkans it is reported from Croatia (Grbac et al. 2019), European Turkey (YiĞit et al. 2008, Danişman et
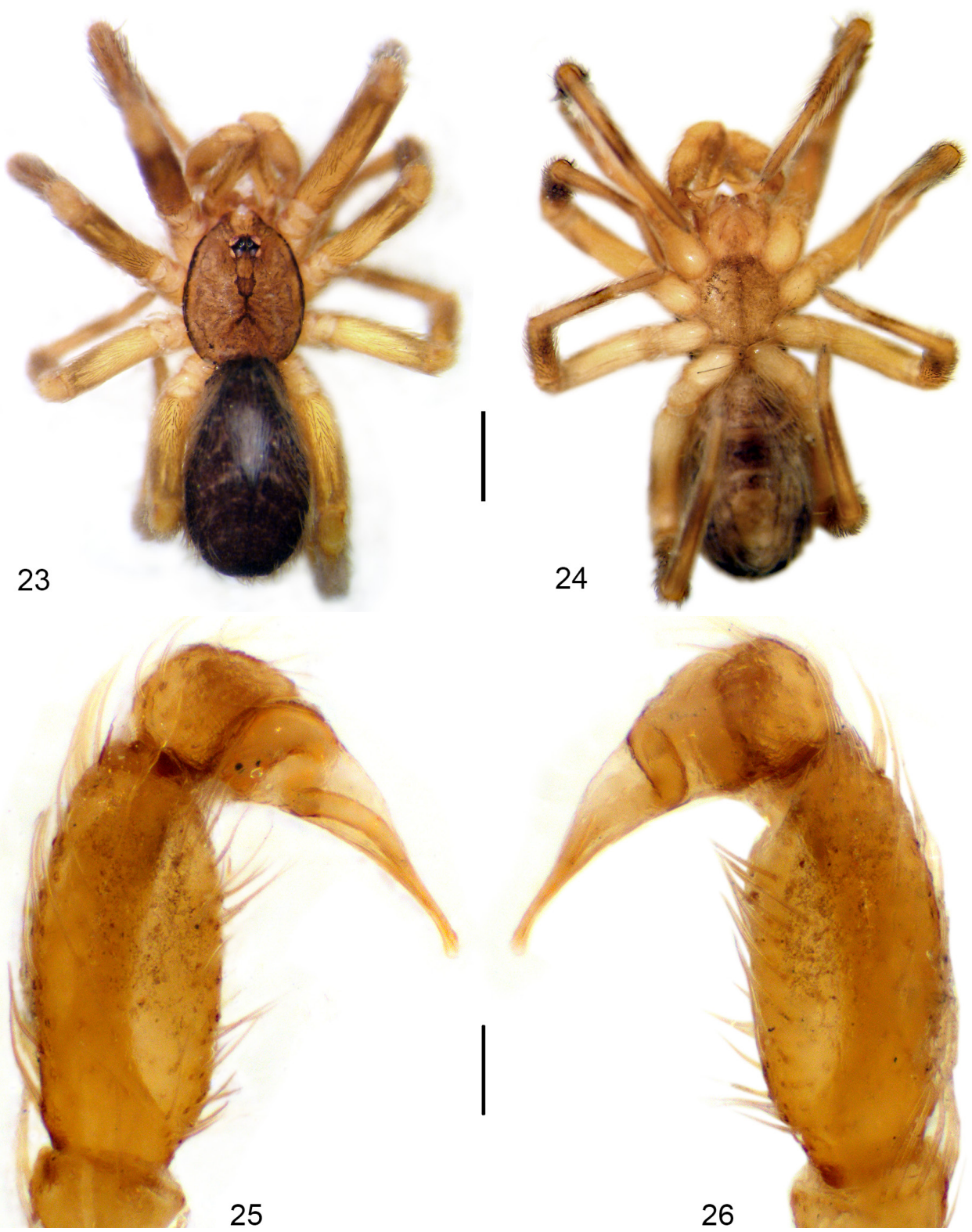

Figs 23-26. Pritha vestita, male. 23 = habitus, dorsal view, $24=$ ditto, ventral view. $25=$ left male palp, prolateral view, $26=$ ditto, retrolateral view. Scale bar: $0.1 \mathrm{~mm}$ 
al. 2019) and Greece (Bosmans \& Chatzaki 2005, Russell-Smith et al. 2011, Bosmans et al. 2013), including Kerkyra (Corfu) Island (Russell-Smith 2014), so finding it in Saranda was not surprising.

\section{DISCUSSION}

Some of our reports could be defined as expected, to the extent that the species are known from adjacent countries and regions, e.g. Altella lucida, Harpactea samuili, Filistata insidiatrix and Loxosceles rufescens, but these records are still notable. Loxosceles rufescens is the most important record, because it is potentially harmful to humans and is one of the most invasive spiders of the world (Nentwig et al. 2017). Harpactea samuili is a Balkan endemic with very limited distribution (Lazarov 2006, Stefanovska et al. 2008) and its ecology is still unknown. Filistata insidiatrix has a wide distribution, but almost all records from the Balkans are extremely old (Zonstein \& Marusik 2019). Altella lucida is a species with a wide distribution in Southern, Central and Eastern Europe and Turkey, but is rarely found (NeNTwig et al. 2020)

After our reports, the known range of Eresus moravicus extends significantly to the east and south-east. We also confirm the cited period of male availability of spring (from late April to June), unlike the adult males of the

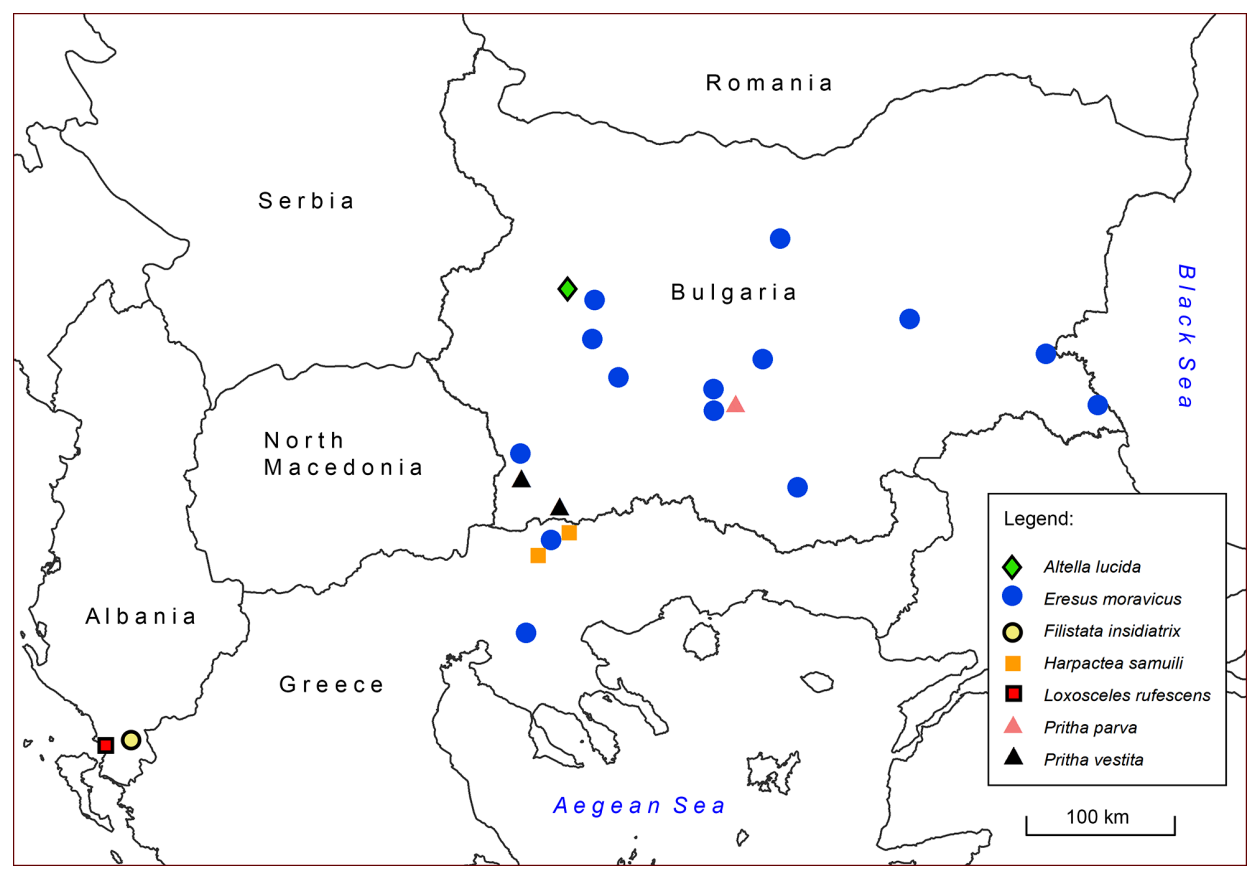

Fig. 27. Map with the localities of the new faunistic records in the Balkan Peninsula 
closest congener E. kollari Rossi, 1846 which occur in autumn (Kovács et al. 2010). Besides, our results suggest that the yellow front of the prosoma of adult females and the overall colouration of males are sufficient to distinguish E. moravicus from E. kollari (Kovács et al. 2015) and can be used for determination in situ or from photos, especially if they are dated. The present records of Pritha parva and P. vestita greatly extend their known range to the east. It is interesting to note that Pritha parva seems to be a synanthropic species (Legittimo et al. 2017, present paper), while P. vestita does not appears to be. The habitats of the type material of $P$. vestita from Corsica island is unknown (Legitтimo et al. 2017). In Bulgaria, it was found in specific natural habitats of evergreen, hard-leaved shrubs and low woods (pseudomaquis), which is critically endangered (Gussev 2015) and is probably suitable for monitoring the condition of this type of plant communities.

As a result of our research, the number of the spiders of Albania, Bulgaria and Greece increased to 571, 1053 and 1183 species, respectively.

Acknowledgement - The authors thank Vasil Genchev, Emiliya Vacheva and Stoyan Lazarov for providing spider material and to Anton Sokolov, Dimitar Dimitrov and Teodor Trifonov for their help during the field work. The research was partially supported, also by the project "Cybertaxonomic approach to phylogenetic studies of model invertebrate genera (Invertebrata, Arachnida, Insecta) clarifying the problems of origin, formation and conservation of the Invertebrate Fauna of the Balkan Peninsula" (National Science Fund, Ministry of Education, Youth and Science of the Republic of Bulgaria, Grant KP-06-H21/1-17.12.2018). S. Zonstein and an anonymous reviewer is thanked for critically reading the manuscript.

\section{REFERENCES}

Blagoev, G., Deltshev, C., Lazarov, S. \& Naumova, M. (2018): The spiders (Araneae) of Bulgaria. [Internet] Version: August 2018. National Museum of Natural History, Bulgarian Academy of Sciences. Available at http://www.nmnhs.com/spiders-bulgaria/ [accessed on 20.08.2020]

BLICK, T. (2018): A small collection of spiders (Arachnida: Araneae) from the River Vjosa, Albania - with an updated spider checklist of Albania. - Acta ZooBot Austria 155: 213-232.

Borges, P. A. V. \& Wunderlich, J. (2008): Spider biodiversity patterns and their conservation in the Azorean archipelago, with descriptions of new species. - Systematics and Biodiversity 6: 249-282. https://doi.org/10.1017/S1477200008002648

Bosmans, R. (unpubl.): Provisional list of spiders of North Africa. - Database excerpt Aug. 2019.

Bosmans, R., Baert, L., Bosselaers, J., De Koninck, H., Maelfait, J.-P. \& van Keer, J. (2009): Spiders of Lesbos (Greece). - Nieuwsbrief van de Belgische Arachnologische Vereniging 24(Suppl.): 1-70. 
Bosmans, R. \& Chatzaki, M. (2005): A catalogue of the spiders of Greece. - Newsletter of the Belgian Arachnological Society 20: 1-124.

Bosmans, R., van Keer, J., Russell-Smith, A., Kronestedt, T. Alderweireldt, M., BosseLAERs, J. \& Koninck, De H. (2013): Spiders of Crete (Araneae). A catalogue of all currently known species from the Greek island of Crete. Arachnological Contributions. - Newsletter of the Belgian Arachnological Society 28(Suppl. 1): 1-147.

Chomphuphuang, N., Deowanish, S., Songsangchote, C., Sivayyapram, V., Thongrrem, P. \& WARrit, N. (2016): The Mediterranean recluse spider Loxosceles rufescens (Dufour, 1820) (Araneae: Sicariidae) established in a natural cave in Thailand. - Journal of Arachnology 44: 142-147. https://doi.org/10.1636/R15-61

Cuttelod, A., Garcia, N., Abdul Malak, D., Temple, H. \& Katariya, V. (2008): The Mediterranean: a biodiversity hot spot under threat. In: VIE, J-C., Hilton-TAYLOR, C. \& StuArt, S. N. (eds): The 2008 Review of The IUCN Red List of Threatened Species. - IUCN, Gland.

Danişman, T., Gündüz, G., Bayram, A., Coşar, İ. \& Allahverdi, H. (2014): Contributions to the knowledge of dictynid spider fauna of Turkey (Araneae, Dictynidae). - Serket 14: 63-67.

Danişman, T., Kunt, K. B. \& ÖZкüтüK, R. S. (2019): The checklist of the spiders of Turkey. - [Internet] Version 2019. Online at http://www.spidersofturkey.info [accessed on 20.08.2020]

Dimitrov, D., Deltshev, C. \& Lazarov, S. (2019): Description of Harpactea popovi sp. n. from Bulgaria with further taxonomic notes on related species (Araneae, Dysderidae). - Zootaxa 4568: 593-600. https://doi.org/10.11646/zootaxa.4568.3.13

Gertsch, W. J. \& Ennik F. (1983): The spider genus Loxosceles in North America, Central America, and the West Indies (Araneae, Loxoscelidae). - Bulletin of the American Museum of Natural History 175: 264-360.

Grbac, I., Katušić, L. \& Lukić, M. (2019): Catalogue of spiders (Araneae) deposited in the Croatian Natural History Museum, Zagreb. - Natura Croatica 28: 185-269. https://doi. org/10.20302/NC.2019.28.19

Grbic, G. \& Savic, D. (2010): Contribution to the knowledge of the spider fauna (Arachnida, Araneae) on the Fruška Gora Mt. - Acta entomologica serbica 15: 243-260.

Griffiths, H. I., Kryštufek, B. \& Reed, J. M. (eds) (2004): Balkan biodiversity - Pattern and process in the European hotspot. - Springer, Berlin. https://doi.org/10.1007/978-1-40202854-0

Gussev, C. (2015): Shrubs and low woods of Kermes Oak (Quercus coccifera). In: Biserkov, V., Gussev, C., Popov, V., Hibaum, G., Roussakova, V., Pandurski, I., Uzunov, Y., Dimitrov, M., Tzonev, R. \& Tsoneva, S. (eds): Red Data Book of the Republic of Bulgaria. Vol. 3. Natural habitats. - IBEI - BAS \& MOEW, Sofia.

Harvey, M. S. (1996): The first record of the Fiddle-back spider Loxisceles rufescens (Araneae: Sicariidae) from Western Australia. - Records of the Western Australian Museum 18: 223-224.

Kovács, G., Prazsák, I., Eichardt, J., VÁr, G. \& Gyurkovics, H. (2015): A new ladybird spider from Hungary (Araneae, Eresidae). - ZooKeys 494: 13-30. https://doi.org/10.3897/ zookeys.494.8676

Kovács, G., Szinetár, C. \& TöRöK T. (2010): [Data on the biology of Eresus species found in Hungary (Eresus kollari Rossi, 1846, Eresus moravicus Rezác, 2008, Araneae: Eresidae)]. A Nyme Savaria Egyetemi Központ Tudományos Közleményei, Szombathely XVII. - Természettudományok 12: 139-156. 
Kovblyuk, M. M., Gnelitsa, V. A., Nadolny, A. A., Kastrygina, Z. A. \& Kukushinin, O. V. (2016): Spiders (Arachnida: Aranei) of the Karadag Nature Reserve (Crimea). - Ekosistemy 3[2015]: 3-288.

KŮrka, A., Naumova, M., Indzhov, S. \& Deltshev, C. (2020): New faunistic and taxonomic data on the spider fauna of Albania (Arachnida: Araneae). - Arachnologische Mitteilungen 59: 8-21. https://doi.org/10.30963/aramit5903

Lazarov, S. (2005): Spiders (Araneae) from Maquises in South-West Bulgaria. Part I. - Acta zoologica bulgarica 57: 145-152.

Lazarov, S. (2006): A new spider species, Harpactea samuili sp. n., from Bulgaria (Araneae: Dysderidae). In: Deltshev, C. \& Stoev, P. (eds): European Arachnology 2005. - Acta zoologica bulgarica 58(Supplement 1): 81-85.

Legittimo, C. M., Simeon, E., Di Pompeo, P. \& Kulczycki, A. (2017): The Italian species of Pritha (Araneae, Filistatidae): a critical revision and description of two new species. - Zootaxa 4243: 201-248. https://doi.org/10.11646/zootaxa.4243.2.1

Mirshamsi, O., Hatami, M. \& Zamani, A. (2013): New record of the Mediterranean recluse spider Loxosceles rufescens (Dufour, 1820) and its bite from Khorasan Province, northeast of Iran (Aranei: Sicariidae). - Iranian Journal of Animal Biosystematics 9: 83-86.

Naumova, M. (2019): Description of Titanoeca deltshevi sp. n. from Bulgaria with faunistic notes on related species in the Balkans (Araneae, Titanoecidae). - Zootaxa 4688: 420-430. https://doi.org/10.11646/zootaxa.4688.3.8

Naumova, M. (2020): Description of two new spider species with new data for the Albanian arachnofauna (Arachnida: Araneae, Opiliones, Pseudoscorpiones \& Scorpiones). - Acta zoologica bulgarica 72: 3-12.

Naumova, M., Hristovski, S. \& Hristov, G. H. (2016): Spiders (Arachnida: Araneae) from Prespa National Park, Albania. - Acta zoologica bulgarica 68: 503-511.

Naumova, M., Indzhov, S., Dimitrov, D. \& Deltshev, C. (2019): Redescription of Dasumia kusceri (Kratochvíl, 1935) with description of the unknown female and notes on the genus Dasumia Thorell, 1875 (Araneae: Dysderidae) in Bulgaria. - Acta zoologica bulgarica 71: 467-472.

Nentwig, W., Blick, T., Bosmans, R., Gloor, D., Hänggi, A. \& Kropf, C. (2020): Araneae. [Internet] Version \{1\}.2020. Online at https://www.araneae.nmbe.ch [accessed on 20.08.2020] https://doi.org/10.24436/1

Nentwig, W., Pantini, P. \& Vetter, R. S. (2017): Distribution and medical aspects of Loxosceles rufescens, one of the most invasive spiders of the world (Araneae: Sicariidae). - Toxicon 132: 19-28. https://doi.org/10.1016/j.toxicon.2017.04.007

PARAsChI, L. (1988): Study of spiders in maquis ecosystems of southern Greece (mainland - insular). - PhD thesis, University of Athens, Department of Biology, Section of Ecology and Taxonomy, $237 \mathrm{pp}$.

Rezác, M., Pekár, S. \& Johannesen, J. (2008): Taxonomic review and phylogenetic analysis of central European Eresus species (Araneae: Eresidae). - Zoologica Scripta 37: 263287. https://doi.org/10.1111/j.1463-6409.2008.00328.x

Roberts, M. J. (1985): The spiders of Great Britain and Ireland, Volume 1: Atypidae to Theridiosomatidae. - Harley Books, Colchester.

Russell-Smith, A. (2014): Spiders from the Ionian islands of Kerkyra (Corfu) and Lefkada, Greece (Arachnida: Aranei). - Arthropoda Selecta 23: 285-300. https://doi.org/10.15298/ arthsel.23.3.08 
Russell-Smith, A., Allison, R., Askins, M., Blumsom, W., Snazell, R. \& Spilling, C. (2011): A provisional checklist and gazetteer of the spiders of Chios, Greece (Arachnida: Araneae). - Bulletin of the British Arachnological Society 15: 133-167. https://doi. org/10.13156/arac.2010.15.5.133

Simon, E. (1873): Aranéides nouveaux ou peu connus du midi de l'Europe. (2e mémoire). Mémoires de la Société Royale des Sciences de Liège (2)5: 187-351. https://doi.org/10.5962/ bhl.title.124166

Simon, E. (1874): Les arachnides de France. - Roret, Paris, pp. 1-272.

Simon, E. (1914): Les arachnides de France. Synopsis générale et catalogue des espèces françaises de l'ordre des Araneae. Tome VI. 1re partie. - Roret, Paris, pp. 1-308.

Stefanovska, D., Naumova, M., Prelik, D., Deltshev, C. \& Lazarov, S. (2008): Spiders from the Skopje region: a faunistic and zoogeographical analysis. - Historia Naturalis Bulgarica 19: 35-49.

Trivedi, V. \& DAL, P. (2019): Occurrence, distribution and description of Loxosceles rufescens (Dufour, 1820) (Araneae: Sicariidae) from western India. - Journal of the Bombay Natural History Society 116: 1-8. https://doi.org/10.17087/jbnhs/2019/v116/123017

WSC (2020): World Spider Catalog. Version 20.0. Natural History Museum Bern, online at http://wsc.nmbe.ch [accessed on 20.08.2020] https://doi.org/10.24436/2

Yiğit, N., Bayram, A., Ulasoglu, D., Danişman, T., Corac Ocal, I. \& SancaK, Z. (2008): Loxosceles spider bite in Turkey (Loxosceles rufescens, Sicariidae, Araneae). - Journal of Venomous Animals and Toxins including Tropical Diseases 14: 178-187. https://doi. org/10.1590/S1678-91992008000100016

Zonstein, S. \& Marusik, Y. M. (2019): A revision of the spider genus Filistata (Araneae: Filistatidae). - Arachnology 18: 53-93. https://doi.org/10.13156/arac.2018.18.2.53

Received August 28, 2020, accepted October 23, 2020, published February 22, 2021 